\title{
Hambatan Prostaglandin pada Pemberian OAINS dan Non-OAINS Pasca Pemakaian Alat Ortodontik
}

\author{
Shanty Sintessa ${ }^{1}$, H.M. Soemarko ${ }^{2}$, Liliek Suprapti ${ }^{3}$, Iwan Hernawan ${ }^{4}$ \\ ${ }^{1}$ Program Studi Pascasarjana S2 Biomedik Universitas Brawijaya, Malang \\ ${ }^{2}$ Bagian Ilmu Bedah Rumah Sakit Umum Syaiful Anwar, Malang \\ ${ }^{3}$ Bagian Ortodontik Poligigi Rumah Sakit Umum Syaiful Anwar, Malang \\ ${ }^{4}$ Ilmu Penyakit Mulut, Fakultas Kedokteran Gigi, Universitas Airlangga, Surabaya
}

\begin{abstract}
Abstrak
Alat ortodontik pada bidang kedokteran digunakan untuk merapikan gigi agar tersusun rapi dan berada pada lengkung rahang. Sehingga mengakibatkan tekanan yang akan merangsang dan menimbulkan reaksi inflamasi jaringan sekitar. Salah satu mediator inflamasi yang mempengaruhi pergerakan gigi adalah prostaglandin ( $\left.\mathrm{PGE}_{2}\right)$. Obat Antiinflamasi Non-Steroid (OAINS) digunakan didalam perawatan ortodontik untuk mengatasi rasa sakit akibat reaksi inflamasi yang terjadi. Sementara itu proses inflamasi diperlukan pada perawatan ortodontik melalui peran $\mathrm{PGE}_{2}$ yang merangsang aktivitas osteoklas dan osteoblas, keduanya diperlukan agar gigi dapat bergerak. Pemilihan jenis selektivitas OAINS perlu diperhatikan mengingat inflamasi diperlukan dalam proses pergerakan gigi tersebut. Penelitian ini bertujuan untuk membandingkan pengaruh selektivitas OAINS dan non OAINS terhadap hambatan $\mathrm{PGE}_{2}$ dan jumlah sel osteoklas osteoblas tulang alveolus gigi rahang atas akibat pemakaian alat ortodontik. Pengamatan dilakukan dengan menggunakan aspirin sebagai OAINS yang selektif terhadap cox 1, diklofenak sebagai OAINS selektif cox 2, dan paracetamol sebagai non OAINS. Pada penelitian ini digunakan hewan coba marmut yang terbagi menjadi kelompok kontrol $(n=6)$, aspirin $87 \mathrm{mg} \cdot \mathrm{kg}^{-1} \mathrm{BB}$ po( $(\mathrm{n}=6)$, diklofenak $2 \mathrm{mg} \cdot \mathrm{kg}^{-1} \mathrm{BB}$ po $(\mathrm{n}=6)$, dan paracetamol $200 \mathrm{mg} \cdot \mathrm{kg}^{-1} \mathrm{BB}$ po $(\mathrm{n}=6)$. Perlakuan dengan alat ortodontik selama 3 hari. Konsentrasi $\mathrm{PGE}_{2}$ diukur dengan spektrofotometer dan sel osteoklasosteoblas dihitung secara histologis. Analisa anova digunakan untuk mebandingkan hambatan $\mathrm{PGE}_{2}$ pada pemberian aspirin, diklofenak, dan paracetamol terhadap kontrol. Uji korelasi untuk menghubungkan hambatan $\mathrm{PGE}_{2}$ terhadap jumlah osteoklas-osteoblas. Hasil penelitian menunjukkan bahwa aspirin, diklofenak, dan paracetamol menurunkan $\mathrm{PGE}_{2}$ dalam tulang dengan signifikan $(p \leq 0,01)$. Penurunan konsentrasi $\mathrm{PGE}_{2}$ berhubungan dengan jumlah osteoklasosteoblas yang terbentuk dengan uji korelasi yang tidak signifikan $(p \geq 0,05)$. Sehingga dapat disimpulkan bahwa pemakaian OAINS dalam waktu 3 hari tidak mempengaruhi proses pergerakan gigi dan paracetamol dapat digunakan sebagai obat penghambat prostaglandin tanpa banyak mempengaruhi proses pergerakan gigi.
\end{abstract}

Kata kunci: $\mathrm{PGE}_{2}, \mathrm{COX}$, OAINS, osteoklas, osteoblas, pergerakan gigi, alat ortodontik.

\begin{abstract}
Orthodontic appliance in the medical field is used to straighten the teeth to be neat and on the arch of jaw, thus lead to the reaction of surround tissue inflammation. One of the inflammation mediator that affect the teeth movement is prostaglandin $\left(\mathrm{PGE}_{2}\right)$. Occurred pain due to inflammation could be overcomed by the administration of OAINS. However, the inflammation itself is needed for the orthodontic care through $\mathrm{PGE}_{2}$ to stimulate the acticvity of osteoclast and osteoblast, both are essential for the teeth movement. Selectivity on OAINS become significant because inflammation is needed in the teeth movement. This study aimed to compare the effect of selectivity of OAINS and non OAINS towards the inhibition of $\mathrm{PGE}_{2}$ and the cell number of osteoclast - osteoblast, on the Alveolar bone of the upper jaw teeth as a result of the use of orthodontic appliances. Aspirin as selective OAINS on cox 1, diclofenac as selective OAINS on cox 2, and paracetamol as non OAINS. We used marmot as experiment animal, grouped into control $(n=6)$, aspirin $87 \mathrm{mg} \cdot \mathrm{kg}^{-1}$ BW po(n=6), diclofenac $2 \mathrm{mg} \cdot \mathrm{kg}^{-1}$ BW po $(\mathrm{n}=6)$, and paracetamol $200 \mathrm{mg} \cdot \mathrm{kg}^{-1} \mathrm{BW}$ po $(\mathrm{n}=6)$. Orthodontic appliance were conducted for 3 days. $\mathrm{PGE}_{2}$ measured by spectrophotometer and cell number of osteoclastosteoblast were counted histologically. ANOVA was used to compare the inhibition of $\mathrm{PGE}_{2}$ on the administration of aspirin, diclofenac, and paracetamol towards control. Correlation analysis was used for the inhibition of $\mathrm{PGE}_{2}$ towards cell number of osteoclast-osteoblast. Results showed that aspirin, diclofenac, and paracetamol decreased $\mathrm{PGE}_{2}$ significantly $(p \leq 0,01)$. The decreased $\mathrm{PGE}_{2}$ was not correlated significantly to the cell number of osteoclast-osteoblast $(p \geq 0,05)$. Thus, we conclude that OAINS use in 3 days is not affecting the teeth movement and paracetamol could be used as medicine to inhibit prostaglandin with less affect on the teeth movement.
\end{abstract}

Keywords: PGE 2 , COX, OAINS, osteoclast, osteoblast, teeth movement, orthodontic appliance

\footnotetext{
* Alamat korespondensi:

Shanty Sintessa

Alamat : Pascasarjana Biomedik, Universitas Brawijaya, Veteran Malang 65145
} 


\section{PENDAHULUAN}

Banyak persoalan gigi yang membuat orang tidak percaya diri diantaranya adalah gigi tonggos atau gigi bertumpuk [1]. Solusi bagi yang ingin giginya rapi adalah dengan menggunakan kawat gigi atau alat ortodontik [2]. Perawatan ortodontik dilakukan berdasarkan suatu prinsip bahwa bila suatu tekanan diberikan cukup lama pada gigi, terjadi pergerakan gigi. Pergerakan gigi terjadi akibat adanya proses resorpsi tulang dan pembentukan tulang atau yang disebut dengan proses remodeling tulang. Resorpsi tulang dilaksanakan oleh osteoklas, sedangkan pembentukan tulang dilaksanakan oleh osteoblas [3].

Prostaglandin sebagai mediator keradangan mempengaruhi osteoklas dan osteoblas melalui reseptornya. Prostaglandin yang berpengaruh adalah jenis Prostaglandin $E_{2}\left(P E_{2}\right)$. $P G E_{2}$ juga sebagai mediator penting dalam pemeliharaan massa dan struktur jaringan tulang terhadap respon kerusakan mekanis dan sintesanya di dalam tulang diatur oleh enzim siklooksigenase (cox) [4]. Terdapat 2 (dua) bentuk isoform cox yaitu cox 1 dan 2. Cox 1 berada pada semua jaringan tubuh, sebaliknya cox 2 merupakan enzim yang ada bila ada sebab dan berada dalam konsentrasi tinggi pada jaringan yang mengalami inflamasi. Obat Anti-inflamasi Non Steroid (OAINS) memiliki kemampuan untuk menghambat sintesa prostaglandin melalui enzim siklooksigenase. Obat OAINS digunakan selama perawatan dengan alat ortodontik bertujuan untuk mengurangi rasa sakit yang ditimbulkan akibat tekanan dari alat ortodontik. Pemilihan jenis OAINS perlu mendapat perhatian karena $\mathrm{PGE}_{2}$ sebagai pencetus rasa sakit, diperlukan dalam mengaktivasi osteoklas dan osteoblas sehinnga gigi dapat bergerak. Oleh karena itu penelitian ini bertujuan untuk membandingkan pengaruh selektivitas OAINS dan non OAINS terhadap hambatan $\mathrm{PGE}_{2}$ dan jumlah sel osteoklas - osteoblas tulang alveolus gigi rahang atas akibat pemakaian alat ortodontik.

\section{METODE}

\section{Persiapan}

Pengamatan dilakukan dengan menggunakan hewan coba marmut dengan BB 350-500 gr dalam kondisi fisik sehat dan diberi makanan jagung. Alat ortodontik dipasang pada gigi seri atas kanan dan kiri. Perlakuan terbagi menjadi 4 (empat) kelompok berjumlah 6 ekor.

1. kelompok I : kontrol adalah marmut yang pemakaian alat ortodontik
2. kelompok II : perlakuan dengan alat ortodontik dengan pemberian aspirin

3. kelompok III: alat ortodontik dengan pemberian diklofenak

4. kelompok IV : alat ortodontik dengan pemberian paracetamol

\section{Pemasangan Alat Ortodontik}

Marmut diletakkan pada meja kerja yang bersih dan sebelumnya ditimbang untuk mengukur berat badan. Suntikan ketalar dengan dosis $44 \mathrm{mgkg}^{-1}$ BB subkutan diberikan setelah marmut dalam kondisi tenang. Bentuk alat ortodontik adalah kawat dengan koil sederhana dengan sudut antara lengan kawat adalah $60^{\circ}$ dan panjang lengan kawat sebesar $1 \mathrm{~mm}$. Stabilisasi alat dengan menggunakan semen yang diguna-kan untuk penambalan gigi. Sebelum dipasang, alat diukur kekuatannya kemudian dipasang pada gigi seri atas diletakkan sepertiga dari tepi gusi dan dilingkarkan diantara gigi seri atas kanan dan kiri. Pemasangan alat ini diharapkan terjadinya pergerakan gigi kearah distal.

\section{Pengambilan Sampel}

Marmut dibunuh dengan menggunakan metode dislokasi dan kemudian dipotong bagian kepala. Separasi rahang atas dengan menggunakan pisau bedah dan mikromotor. Rahang yang didapatkan kemudian dengan menggunakan mikromotor diambil $10 \mathrm{mg}$ untuk pengukuran kadar $\mathrm{PGE}_{2}$. Rahang yang masih ada ditampung dan diberi asam sitrat selama 36 jam untuk dekalsifikasi. Tulang rahang hasil dekalsifikasi ditanam dalam parafin dan dipotong untuk dibuat slide preparat pengecatan.

\section{Pengukuran Konsentrasi PGE}

Serbuk dari tulang rahang ditambah dengan buffer tris- $\mathrm{HCl}$ sebanyak $1 \mathrm{cc}$ pada suhu $5^{\circ} \mathrm{C}$ selama 1 menit dengan tujuan memisahkan tulang alveolus yang sudah hancur dari jaringan ikat dan lemak. Homogenat disentrifugasi selama 10 menit pada 12,000 x g dan menghasilkan larutan supernatan. Supernatan kemudian difiltrasi dengan dua lapis kain katun dan disentrifugasi kembali selama 2,5 jam sehingga menghasilkan precipitat kemudian diinkubasi selama 3-5 detik pada suhu $37^{\circ} \mathrm{C}$. Pemeriksaan dilanjutkan dengan penambahan $\mathrm{KOH}$ dalam methanol, dan methanol untuk memisahkan $\mathrm{PGE}_{2}$. Tube dibiar-kan pada suhu ruangan selama 15 menit dan diabsorbsi pada panjang gelombang $(\lambda)=278 \mathrm{~nm}$. Hasil pembacaan PGE 2 dari tulang alveolus terse-but kemudian 
dicocokkan dengan kurva baku yang telah dibuat sebelumnya. Pengecatan Secara Histologis dengan Metode Hematoksilin-Eosin Untuk Menghitung Jumlah Osteoklas dan Osteoblas

Slide hasil potongan diletakkan pada kaca preparat kemudian dilakukan rehidrasi ulang dengan alkohol bertingkat yaitu absolut 96\%, $80 \%, 70 \%, 50 \%, 30 \%$ dan ditambah dengan aquadest. Tetesi dengan meyer hematoksilin selama 10 menit dengan jumlah sekitar $500 \mu l$. Cuci dengan air mengalir kemudian dehidrasi dengan alkohol bertingkat dari 30\%, 50\%, dan 70\%. Tetesi dengan eosin selama 1 menit dan cuci kembali dengan alkohol bertingkat mulai dari $70 \%$, 50\%, dan 30\%. Bilas dengan aquadest dan keringkan dengan angin.

\section{Analisis Data}

Data hasil pengukuran konsentrasi $\mathrm{PGE}_{2}$ sampel antar perlakuan dianalisa dengan menggunakan $t$ test. Pengaruh hambatan $\mathrm{PGE}_{2}$ terhadap jumlah osteoklas dan osteoblas dengan menggunakan korelasi.

\section{HASIL DAN PEMBAHASAN}

Pengaruh Pemberian Aspirin, Diklofenak, dan Paracetamol Terhadap Kadar PGE 2

Pengamatan telah dilakukan untuk mengetahui hambatan $\mathrm{PGE}_{2}$ pada pemberian aspirin, diklofenak, dan paracetamol terhadap pergerakan gigi dan jumlah sel osteoklas dan osteoblas tulang alveolus rahang atas akibat pemakaian alat ortodontik. Pada hasil pengamatan didapatkan perbedaan yang cukup bermakna dari hambatan $\mathrm{PGE}_{2}$ pada pemberian aspirin, diklofenak, dan paracetamol (Tabel 1).

Hal ini dapat dijelaskan bahwa pemakaian obat aspirin, diklofenak, dan paracetamol dapat menurunkan konsentrasi $\mathrm{PGE}_{2}$. Aspirin dan diklofenak merupakan obat OAINS. Mekanisme kerja obat tersebut adalah menghambat produksi $\mathrm{PGE}_{2}$ melalui hambatan enzim cox [5]. Terdapat 2 bentuk isoform cox yaitu cox 1 dan 2. Cox 1 berada pada semua jaringan tubuh tetapi konsentrasi yang tinggi berada dalam ginjal saluran gastrointestinal dan platelet. Fungsi utama pada saluran gastrointestinal adalah untuk memelihara keutuhan mukosa [6].

Berdasarkan selektivitas hambatan pada cox, OAINS dikelompokkan menjadi selektif terhadap cox 1 dan cox 2. Aspirin masuk pada golongan yang lebih selektif terhadap cox 1 . Pada pengamatan didapatkan hasil hambatan $\mathrm{PGE}_{2}$ oleh aspirin lebih kecil bila dibandingkan dengan diklofenak (Gambar 1). Diklofenak termasuk dalam golongan OAINS yang selektif menghambat cox 2. Hal ini dapat dijelaskan bahwa cox 2 terutama sebagai enzim yang ada bila ada sebab. Ekspresi cox 2 yang rendah dapat ditingkatkan pengaturannya oleh beberapa rangsangan termasuk sitokin keradangan, racun bakteri, dan growth factor. Cox 2 berperan dalam proses keradangan, infeksi, dan ploriferasi sel. Cox 2 berada pada konsentrasi tinggi pada jaringan yang mengalami keradangan [6]. Alat ortodontik ditetapkan sebagai penyebab tekanan [7]. Tekanan mekanis akibat pemakaian alat ortodontik menimbulkan proses keradangan pada jaringan periodontal sehingga permeabilitas pembuluh darah jaringan tersebut meningkat 20 menit setelah pemakaian alat [8].

Paracetamol juga diketahui sebagai obat yang mampu menghambat produksi $\mathrm{PGE}_{2}$ yang bekerja pada pusat susunan syaraf melalui cox 3 . Cox 3 diproduksi berlimpah hanya di dalam korteks serebral. Oleh karena itu hanya sedikit dalam menghambat PGE 2 lokal (Tabel 2).

Tabel 1. Rerata hambatan kadar $\mathrm{PGE}_{2}$ pada pemberian aspirin, diklofenak, paracetamol

\begin{tabular}{|c|c|c|c|c|}
\hline Kelompok & Rerata & stdev & Analisa & Sig. \\
\hline Kontrol (K) & 29.867 & 1.086 & & \\
\hline & & & $\left.{ }^{*}\right)$ Uji anova & * $P \leq 0.05$ \\
\hline Aspirin (A) & 18.483 & 1.501 & $p=0,0001$ & \\
\hline Diklofenak (D) & 9.000 & 5.734 & $\begin{array}{c}* *) \text { Uji Duncan } \\
p=1,000\end{array}$ & $* *$ \\
\hline Paracetamol (P) & 25.600 & 1.867 & & $P \geq 0,05$ \\
\hline
\end{tabular}

Keterangan :

*) uji statistik terhadap rerata kadar $\mathrm{PGE}_{2}$ pada kelompok kontrol, aspirin, diklofenak, dan paracetamol, terdapat perbedaan yang cukup bermakna antara keempat kelompok tersebut $(p \leq 0,05)$

**) uji statistika kadar $\mathrm{PGE}_{2}$ tidak didapati kelompok perlakuan yang paling menghambat $\mathrm{PGE}_{2}(p \geq 0,05)$. 


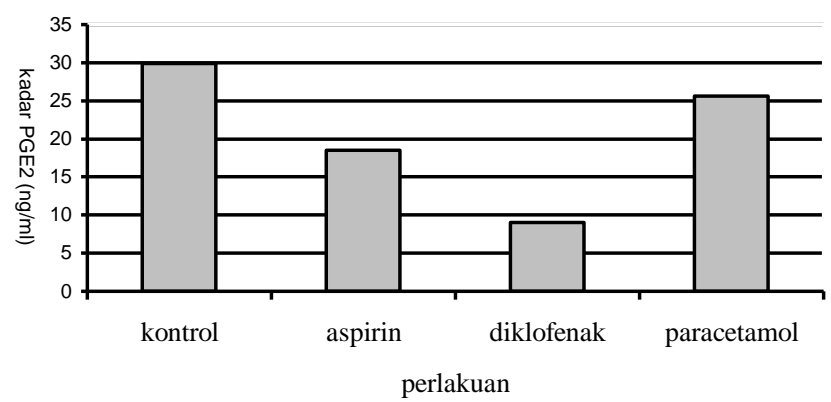

Gambar 1. Kadar $\mathrm{PGE}_{2}$ pada perlakuan kontrol (K) tanpa pemberian obat, dengan pemberian aspirin (A), diklofenak (D), dan paracetamol (P). Pada uji anova didaptkan adanya perbedaan yang cukup bermakna $((p \leq 0,05)$ antara perlakuan, namun pada uji Duncan tidak didapatkan perbedaan yang bermakna $((p \geq 0,05)$.

Tabel 2. Uji Tukey HSD kadar PGE 2

\begin{tabular}{ccccc}
\hline Perlakuan & K & A & D & P \\
\hline K & - & 0.000 & 0.000 & 0.122 \\
A & 0.000 & - & 0.000 & 0.004 \\
D & 0.000 & 0.000 & - & 0.000 \\
P & 0.122 & 0.004 & 0.000 & \\
\hline
\end{tabular}

Keterangan:

$\mathrm{K}=$ kelompok kontrol

$A=$ kelompok aspirin

$\mathrm{D}=$ kelompok diklofenak

$\mathrm{P}=$ kelompok paracetamol

Cox 3 merupakan turunan dari gen $\operatorname{cox} 1$ dengan perbedaan yang terletak pada intron pada mRNAnya. Cox 3 diekspresikan pada korteks serebral dan hanya dalam jumlah sangat sedikit pada jaringan lain. Pada manusia, mRNA cox 3 diekspresikan berlimpah di korteks serebral dan jantung. Simmona and Colleagues berhasil mengidenti-fikasi suatu enzim yang disebut dengan cox 3. Cox 3 merupakan bentuk isoform dari cox 1 tetapi diekspresikan apabila ada sebab. Kemungkinan lain bahwa cox 3 dihasilkan dari gen yang sama untuk mengkode ekspresi cox 2 dengan karakter molekuler yang berbeda. Hambatan cox 3 menggambarkan mekanisme obat yang bekerja pada sentral sehingga rasa sakit dapat tertangani dan kemungkinan juga demam. Secara selektif cox 3 hanya dapat dihambat oleh OAINS tertentu dan memiliki sensitifitas yang tinggi pada paracetamol [9]. Sebagian besar menganggap bahwa paracetamol merupakan jenis OAINS dengan kemampuan sebagai anti keradangan yang sedikit [9]. Paracetamol dapat menghambat rasa sakit dan demam seperti pada umumnya OAINS. Paracetamol lebih dikenal sebagai obat penghilang rasa sakit atau penurun panas.

Pada pengamatan yang telah dilakukan oleh Flower and Vane [9], menunjukkan bahwa paracetamol menghambat aktifitas enzim cox di bagian otak lebih besar pengaruhnya dibanding bagian limfa. Bahkan cox 1 dan 2 tetap pada konsentrasi yang tinggi meskipun dosis paracetamol sudah dinaikkan. Berdasarkan hal tersebut maka dicurigai adanya isoenzim lain yang terkait langsung dengan kerja dari paracetamol [9].

Pengaruh pemberian aspirin, diklofenak, dan paracetamol pada pergerakan gigi

Hasil pengukuran pergerakan gigi pada pengamatan menunjukkan bahwa pemberian aspirin, diklofenak, dan paracetamol tidak terdapat perbedaan pada pergerakan gigi akibat pemakaian alat ortodontik selama 3 hari (Tabel 3, Gambar 2). Semua jenis OAINS berhubungan dengan hambatan pembentukan prostaglandin. Penga-ruh anti radang, anti demam, dan analgesik dari OAINS melalui hambatan cox 2 .

Tabel 3. Rerata pergerakan gigi pada pemberian aspirin, diklofenak, dan paracetamol

\begin{tabular}{|c|c|c|c|c|}
\hline Kelompok & Rerata & stdev & Analisa & Sig. \\
\hline Kontrol (K) & 0.867 & 0.151 & \multirow{4}{*}{$\begin{array}{l}\left.{ }^{*}\right) \text { Uji } \\
\text { anova } \\
p=0,968\end{array}$} & \multirow{4}{*}{$\begin{array}{c}P \geq \\
0.05\end{array}$} \\
\hline Aspirin (A) & 0.883 & 0.147 & & \\
\hline Diklofenak (D) & 0.900 & 0.110 & & \\
\hline $\begin{array}{l}\text { Paracetamol } \\
\text { (P) }\end{array}$ & 0.900 & 0.126 & & \\
\hline Keterangan: & & & & \\
\hline
\end{tabular}

Hambatan produksi prostaglandin dipercaya merupakan mekanisme utama dari aksi OAINS melalui hambatan enzim cox dari asam arakhidonat. Penggunaan dari OAINS dapat menghambat pembentukan tulang karena hambatan pembentukan prostaglandin, tetapi tidak semua jenis NSAIDs. Jenis propionik mencegah hilangnya tulang pada beberapa 
keadaan sekitarnya tetapi jenis asam asetat tidak. Dosis dan lama penggunaan juga merupakan faktor yang mempengaruhi hambatan pembentukan tulang [5]. Pengamatan pada babi dengan menggunakan indomethacin menunjukkan bahwa permukaan resorpsi yang relatif luas berkurang secara bermakna, permukaan pembentukan juga menurun tetapi tidak bermakna [10], sehingga hambatan prostaglandin perlu dihindari selama perawatan dengan alat ortodontik. Pengamatan juga dilakukan dengan pemberian indomethacin injeksi subkutan.

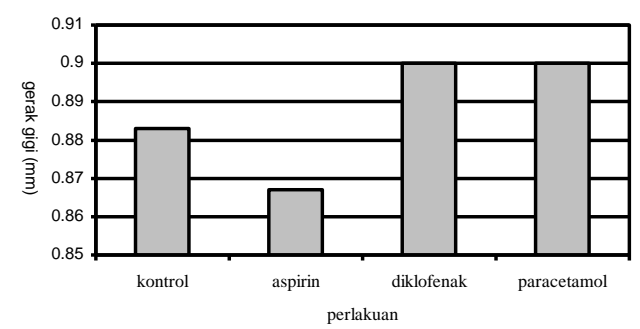

Gambar 2. Besar gerakan gigi pada perlakuan kontrol (K) tanpa pemberian obat, dengan pemberian aspirin (A), diklofenak (D), dan paracetamol (P). Pada uji anova didapatkan tidak adanya perbedaan yang bermakna $(p \geq 0,05)$ antara perlakuan.

Pemberian indomethacin dilakukan pada kelompok sebelum dibandingkan dengan sebelum memakai alat ortodontik. Pengamatan dilakukan setelah 3 hari pemakaian alat ortodontik. Hasil yang didapatkan menunjukkan bahwa pada pemberian setelah pemakaian alat ortodontik, memiliki pengaruh yang sangat kecil terhadap penekanan jumlah osteoklas. Pada pemberian sebelum pemakaian menunjukkan hasil yang sebaliknya yaitu terdapat penekanan jumlah osteoklas yang cukup bermakna. Berdasarkan hasil tersebut maka apabila resorpsi tulang akan dihambat, pemberian indometachin akan lebih efektif jika diberikan sebelum pemakaian alat ortodontik [8]. Pergerakan karena alat ortodontik tergantung dari remodeling tulang tetapi mekanisme rangsangan mekanis yang dipindahkan ke dalam reaksi seluler belum secara keseluruhan dijelaskan. Beberapa faktor yang terlibat adalah neurotransmitter, siklik nukletida, sitokin, dan prostaglandin [10]. Gerakan gigi akibat pemakaian alat ortodontik mengakibatkan remodeling tulang yang berlanjut selama beberapa hari setelah pelepasan pemakaian alat yang sesuai dengan beban, karena alat ortodontik merangsang resorpsi tulang pada sisi yang menerima beban tekanan. Perawatan orto dontik dilakukan berdasarkan suatu prinsip bahwa bila suatu tekanan diberikan cukup lama pada gigi, terjadi pergerakan karena tulang di sekeliling berubah [11].

Respon lokal akibat pemakaian alat ortodontik dipengaruhi oleh faktor sistemik seperti hormon paratiroid dan vitamin D [8]. Pemberian terapi hormon sulit dilakukan pada saat perawatan ortodontik karena pengaruhnya bersifat sistemik. Pemberian prostaglandin lebih memungkinkan dilakukan secara lokal untuk meningkatkan resorpsi tulang sehingga pergerakan gigi diharapkan lebih cepat terjadi [8].

Pengaruh pemberian aspirin, diklofenak, dan paracetamol terhadap jumlah sel osteoklas dan osteoblas

Tabel 4 dan Gambar 3 di bawah berikut digunakan untuk menjelaskan pengaruh pemberian aspirin, diklofenak, dan paracetamol terhadap jumlah sel osteoklas dan osteoblas. Hasil menunjukkan bahwa tidak didapatkan perbedaan yang bermakna antara penurunan jumlah sel osteoklas dan osteoblas pada pemberian aspirin, diklofenak, dan parcetamol. Kemungkinan apabila pengamatan dilakukan lebih dari 3 hari, maka pemberian aspirin, diklofenak, dan paracetamol dapat terlihat nyata perbedaannya, karena tulang alveolus melanjutkan remodeling tanpa secara langsung selama beberapa minggu setelah bergeraknya terhadap beban alat ortodontik [11]. Pergantian tulang tetap meningkat setelah pemakaian alat ortodontik [11]. Pergerakan gigi dengan menggunakan alat ortodontik tergantung pada remodeling tulang [10].

Proses remodeling tulang merupakan proses yang kompleks dan terkoordinasi yang terdiri dari proses resorpsi dan pembentukan tulang yang menghasilkan pertumbuhan dan pergantian tulang. Hasil akhir dari remodeling tulang adalah terpeliharanya matriks tulang. Proses pembentukan pada tulang dewasa hanya terjadi bila didahului oleh proses resorpsi tulang. Jadi urutan proses yang terjadi pada tempat remodeling adalah aktifasi-resorpsi-pembentukan [12]. 
Tabel 4. Rerata jumlah sel osteoklas pada pemberian aspirin, diklofenak, dan paracetamol

\begin{tabular}{|c|c|c|c|c|c|c|}
\hline Kelompok & osteoklas & stdev & Analisa & osteoblas & stdev & Analisa \\
\hline Aspirin (A) & 14.33 & 5.82 & \multirow{2}{*}{$\begin{array}{l}\text { *) Uji Anova } \\
\quad p=0,464 \\
\text { (tidak bermakna) }\end{array}$} & 39.50 & 11.36 & \multirow{2}{*}{$\begin{array}{l}\text { *) Uji Anova } \\
\text { p }=0,948 \\
\text { (tidak bermakna) }\end{array}$} \\
\hline Paracetamol (P) & 13.17 & 2.14 & & 40.33 & 11.29 & \\
\hline
\end{tabular}

Keterangan :

*) uji statistik terhadap rerata jumlah sel osteoklas dan osteoblas pada kelompok kontrol, aspirin, diklofenak, dan paracetamol, tidak terdapat perbedaan yang cukup bermakna $(p \geq 0,05)$.

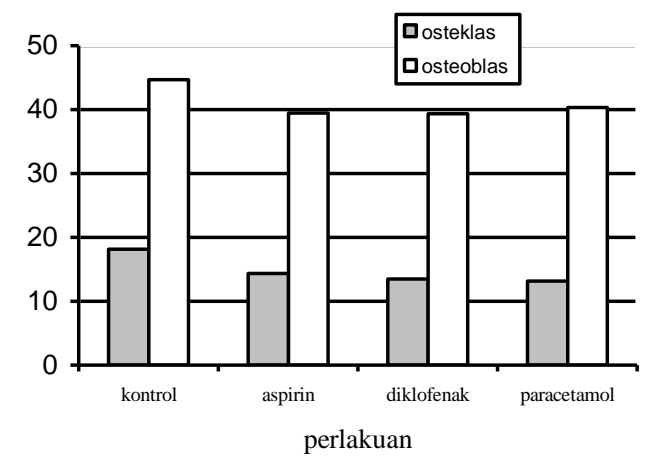

Gambar 3. Jumlah sel osteoklas dan osteoblas pada perlakuan kontrol (K) tanpa pemberian obat, dengan pemberian aspirin $(A)$, diklofenak (D), dan paracetamol (P). Pada uji anova didapatkan tidak adanya perbedaan yang bermakna $(p \geq$ $0,05)$ dari jumlah osteoklas dan osteoblas antara perlakuan

BSP (bone sialoprotein) terlibat dalam mineralisasi tulang selama remodeling tulang secara fisiologis. Pada pemberian tekanan dari alat ortodontik, osteoblas diaktifkan dan diinduksi oleh mRNA yang diekspresikan oleh BSP. BSP ini terlibat dalam proses remodeling tulang selama pemakaian alat ortodontik [13]. Yun Cho [14] telah mengamati remodeling tulang alveolus pada pemakaian alat ortodontik yang diamati pada hari ke 1, 3, 5, 7, 14, dan 21. Hasil penelitian menunjukkan bahwa pada hari 1 osteoklas mulai aktif dan berada pada puncak aktivasi pada hari ke 3 . pengamatan hari ke 3 menunjukkan bahwa osteoblas mulai aktif dan puncak aktivasi terjadi pada hari ke 14.

Osteoblas didapatkan pada daerah pembentukan tulang remodeling dan penyembuhan patah tulang. Aktivitas osteoblas ini selalu disertai aktivitas osteoklas [15]. Osteoblas merupakan sumber utama dari produksi prostaglandin dalam tulang [16]. Faktor yang mempengaruhi diferensiasi osteoblas antara lain BMP (Bone Morphogenetic Protein) oleh berbagai sitokin lain seperti interleukin, Insulin Growth Factor (IGF), dan Pleteled Derived Growth Factor (PDGF). Berbagai sitokin dan BMP telah terbukti mempengaruhi diferensiasi osteoblas secara invitro. Aktivitas osteoblas selalu disertai aktivitas osteoklas. Kerjasama osteoklas dan osteoblas dalam peristiwa resorpsi dan deposisi tulang merupakan mekanisme yang berpasangan. Osteoblas dapat mengalami apoptosis bila regulasi sintesis berhenti, dan osteosit rusak bila matriks mengalami siklus ulang [17]. Osteoklas merupakan sel yang mendasari terjadinya pergerakan gigi akibat alat ortodontik [17]. Osteoklas adalah makrofag polikarion khusus yang diferensiasinya terutama diatur oleh macrofag colony stimulating factor, RANK ligand dan osteoprotegerin. Integrinmediated signal menyebabkan osteoklas menunjukkan sitoskleton yang memungkinkan terbentuknya microenvironment tertentu antara dirinya dengan tulang dan kemudian terjadi degradasi matriks melalui proses transport proton [17]. Terjadinya remodeling tulang disebabkan oleh pemakaian alat ortodontik mengakibatkan jumlah osteoklas lebih banyak terdapat didaerah yang mengalami tekanan, sedangkan di daerah tarikan lebih banyak dijumpai sel osteoblas. Jumlah osteoklas dipengaruhi selain oleh besarnya tekanan juga oleh lamanya pemakaian alat. Selama pemakaian alat ortodontik sampai hari ke 16 menunjukkan bahwa adanya peninggian osteoklas di bagian mesial pada hari pertama setelah pemakaian alat digambarkan bahwa gelombang kedua dari sel 
yang mengalami resorpsi, dilanjutkan dengan pergantian tulang alveolus setelah pemasangan alat dan pergerakan gigi juga perubahan secara histologis [11] sesuai dengan beban jaringan secara langsung, berlanjut pada waktu setelah pemakaian alat. Resorpsi merupakan proses awal dari remodeling tulang pada pemakaian alat ortodontik [18].

Uji Korelasi Hambatan $\mathrm{PGE}_{2}$ dengan Pergerakan Gigi dan Uji Korelasi Hambatan $\mathrm{PGE}_{2}$ dengan Jumlah Sel Osteoklas

Uji korelasi hubungan antara hambatan $\mathrm{PGE}_{2}$ dengan pergerakan gigi (Tabel 5) dan jumlah sel osteoklas (Tabel 6) menunjukkan bahwa hanya pada perlakuan tanpa pemberian obat dan dengan pemberian diklofenak terdapat hubungan dan hubungannya bersifat berlawanan. Artinya penurunan kadar $\mathrm{PGE}_{2}$ diikuti penambahan besar pergerakan gigi dan jumlah sel osteoklas, sedang pada pemberian aspirin dan paracetamol terdapat hubungan penurunan kadar $\mathrm{PGE}_{2}$ dengan perge-rakan gigi tetapi tidak bermakna. Hal ini dapat dijelaskan karena sifat $\mathrm{PGE}_{2}$ yang biphasic. Pengaruh biphasic $\mathrm{PGE}_{2}$ pada aktivitas alkalin fosfatase kemungkinan dimediasi melalui penga-ruh rangsangan reseptor $\mathrm{EP}_{4}$ dalam kadar yang rendah dan pengaruh hambatan dari kadar $\mathrm{EP}_{1}$ yang tinggi [19]. Prostaglandin merupakan senyawa yang yang menyerupai hormon dan berperan penting pada berbagai proses fisiologis. Prostaglandin diproduksi secara lokal dan merangsang aktifitas sel didekat sisi produksi prostaglandin. Proses metabolisme prostaglandin berlangsung secara cepat dan pengaruhnya terhadap jaringan beraneka tergantung pada jenis prostaglandin dan jaringannya [20].

$\mathrm{PGE}_{2}$ bekerja dengan perantara reseptor membran. Terdapat empat sub tipe reseptor $P E_{2}$ yaitu $E P_{1}, E P_{2}, E P_{3}$, dan $E P_{4}$, yang masingmasing disandi oleh gen yang berbeda. Reseptor tersebut diekspresikan berbeda oleh sel imun, dan fungsi sel imun tersebut akan berbeda tergantung adanya $\mathrm{PGE}_{2}$ pada daerah keradangan. Reseptor melanjutkan reaksi intraseluler setelah berikatan dengan ligan. Reseptor $\mathrm{EP}_{2}$ dan $\mathrm{EP}_{4}$ adalah suatu bentuk reseptor isoform dengan $E P_{3}$ yang dapat berpasangan dengan $G$ protein untuk meningkatkan cAMP intraseluler.

Reseptor $E_{1}$ menyebabkan peningkatan kadar calsium intraseluler. $\mathrm{EP}_{3}$ berpasangan dengan $\mathrm{Gi}$ protein mengakibatkan penurunan CAMP, juga mobilisasi kalsium intraseluler. Jadi terdapat efek yang berlawanan pada banyak sel imun yang terekspresi pada banyak reseptor. Pengaturan $\mathrm{EP}_{2}$ dan $\mathrm{EP}_{4}$ dapat dijadikan contoh mekanisme pangaturan sel atas respon $\mathrm{PGE}_{2}$.

Walaupun kedua reseptor berikatan dengan $\mathrm{PGE}_{2}$ secara seimbang dan berpasangan dengan Gs protein, sejumlah penelitian menunjukkan prostagladin ini tidak mempunyai fungsi selular yang serupa. Terdapat perbedaan respon sel pada masing-masing reseptor. Jadi pengaruh $\mathrm{PGE}_{2}$ selama proses keradangan pada sel imun ditentukan susunan reseptor yang terekspresi dan intracellular pathway dari sel.

Belum banyak pengamatan tentang peranan reseptor tersebut, tetapi terdapat petunjuk bahwa $\mathrm{PGE}_{2}$ merangsang diferensiasi osteoblas melalui reseptor $\mathrm{EP}_{4}$ pada pengamatan dengan menggunakan kultur bone marrow [4].

Tabel 5. Korelasi pearson antara kadar $\mathrm{PGE}_{2}$ dengan besar pergerakan gigi

\begin{tabular}{|c|c|c|c|c|c|}
\hline \multirow{2}{*}{ Sel osteoklas } & \multirow{2}{*}{ Nilai uji korelasi } & \multicolumn{4}{|c|}{ Kadar $\mathrm{PGE}_{2}$} \\
\hline & & Kontrol & Aspirin & Diklonefak & Paracetamol \\
\hline \multirow{3}{*}{ Kontrol } & Korelasi pearson & -0.528 & & & \\
\hline & $\mathrm{p}$ & 0.282 & & & \\
\hline & $\mathrm{n}$ & 6 & & & \\
\hline \multirow{3}{*}{ Aspirin } & Korelasi pearson & & 0.349 & & \\
\hline & $\mathrm{p}$ & & 0.498 & & \\
\hline & $\mathrm{n}$ & & 6 & & \\
\hline \multirow{3}{*}{ Diklonefak } & Korelasi pearson & & & -0.248 & \\
\hline & $\mathrm{p}$ & & & 0.636 & \\
\hline & $n$ & & & 6 & \\
\hline \multirow{3}{*}{ Paracetamol } & Korelasi pearson & & & & -0.271 \\
\hline & $p$ & & & & 0.604 \\
\hline & $\mathrm{n}$ & & & & 6 \\
\hline
\end{tabular}

Keterangan : Dinyatakan ada korelasi apabila $0,2 \leq r$ atau $r \leq-0,2$. Korelasi bermakna apabila $p \leq 0,05 . n=$ jumlah sampel 
Tabel 6. Korelasi pearson antara kadar $\mathrm{PGE}_{2}$ dengan jumlah sel osteoklas

\begin{tabular}{|c|c|c|c|c|c|}
\hline \multirow{2}{*}{ Sel osteoklas } & \multirow{2}{*}{ Nilai uji korelasi } & \multicolumn{4}{|c|}{ Kadar PGE 2} \\
\hline & & Kontrol & Aspirin & Diklonefak & Paracetamol \\
\hline \multirow{3}{*}{ Kontrol } & Korelasi pearson & -0.528 & & & \\
\hline & $\mathrm{p}$ & 0.282 & & & \\
\hline & $\mathrm{n}$ & 6 & & & \\
\hline \multirow{3}{*}{ Aspirin } & Korelasi pearson & & 0.349 & & \\
\hline & $\mathrm{p}$ & & 0.498 & & \\
\hline & $\mathrm{n}$ & & 6 & & \\
\hline \multirow{3}{*}{ Diklonefak } & Korelasi pearson & & & -0.248 & \\
\hline & $\mathrm{p}$ & & & 0.636 & \\
\hline & $\mathrm{n}$ & & & 6 & \\
\hline \multirow{3}{*}{ Paracetamol } & Korelasi pearson & & & & -0.271 \\
\hline & $\mathrm{p}$ & & & & 0.604 \\
\hline & $\mathrm{n}$ & & & & 6 \\
\hline
\end{tabular}

Keterangan : Dinyatakan ada korelasi apabila $0,2 \leq r$ atau $r \leq-0,2$. Korelasi bermakna apabila $p \leq 0,05$. $n=$ jumlah sampel

Peranan reseptor $\mathrm{EP}_{4}$ terhadap pembentukan osteoklas juga telah dilakukan melalui pemberian obat antagonis reseptor tersebut dan menunjukkan adanya hubungan dengan resorpsi tulang [4]. Peranan $\mathrm{EP}_{2}$ diduga berpengaruh pada pertumbuhan jaringan tulang [4] Reseptor $\mathrm{PGF}_{2 \alpha}$ memediasi kemampuan prostaglandin dalam menghambat sintesis kolagen dan menginduksi prostaglandin $\mathrm{G} / \mathrm{H}$ sintase didalam sel.

Uji Korelasi Hambatan $\mathrm{PGE}_{2}$ dengan Jumlah Sel Osteoblas dan Uji Korelasi Pergerakan Gigi dengan Jumlah Sel Osteoklas

Proses bergeraknya gigi akibat pemakaian alat ortodontik adalah merupakan hasil dari respon biologis terhadap tekanan mekanis. Perubahan yang terjadi pada tulang akibat tekanan mekanis antara lain terjadi resorpsi tulang, pembentukan tulang, dan perubahan yang terjadi pada ligamen periodontal, perubahan komposisi kimia dan perubahan enzimatik [8]. Pembuktian peranan prostaglandin terhadap pergerakan gigi telah dilakukan. Pengamatan ini dilakukan dengan cara memberikan injeksi submukosa prostaglandin. Hasilnya terdapat jumlah osteoklas yang lebih banyak jika dibandingkan dengan kontrol dan resorpsi tulang lebih besar terjadi (Tabel 7 dan 8). Prostaglandin dihasilkan dari membran lipid jaringan periodontal pada daerah bebas. Tekanan mekanis dari alat ortodontik menimbulkan gangguan membran sel jaringan periodontal sehingga sintesis dan sekresi prostaglandin meningkat. Mekanisme peranan prostaglandin melalui cAMP dan kalsium intrasel [8].

Tabel 7. Korelasi pearson antara kadar $\mathrm{PGE}_{2}$ dengan jumlah sel osteoblas

\begin{tabular}{|c|c|c|c|c|c|}
\hline \multirow{2}{*}{ Osteoblas } & \multirow{2}{*}{ Nilai uji korelasi } & \multicolumn{4}{|c|}{ Kadar PGE ${ }_{2}$} \\
\hline & & Kontrol & Aspirin & Diklonefak & Paracetamol \\
\hline \multirow{3}{*}{ Kontrol } & Korelasi pearson & 0.226 & & & \\
\hline & $p$ & 0.666 & & & \\
\hline & $\mathrm{n}$ & 6 & & & \\
\hline \multirow{3}{*}{ Aspirin } & Korelasi pearson & & 0.098 & & \\
\hline & $\mathrm{p}$ & & 0.854 & & \\
\hline & $\mathrm{n}$ & & 6 & & \\
\hline \multirow{3}{*}{ Diklonefak } & Korelasi pearson & & & 0.495 & \\
\hline & $p$ & & & 0.318 & \\
\hline & $\mathrm{n}$ & & & 6 & \\
\hline \multirow{3}{*}{ Paracetamol } & Korelasi pearson & & & & 0.760 \\
\hline & $\mathrm{p}$ & & & & 0.079 \\
\hline & $\mathrm{n}$ & & & & 6 \\
\hline
\end{tabular}

Keterangan :K=kontrol, $A=$ aspirin, $D=$ diklofenak, $P=$ paracetamol. Dinyatakan ada korelasi apabila $0,2 \leq r$ atau $r \leq-0,2$. Korelasi bermakna apabila $p \leq 0,05 . n=$ jumlah sampel 
Tabel 8. Korelasi pearson antara pergerakan gigi dengan jumlah sel osteoklas

\begin{tabular}{|c|c|c|c|c|c|}
\hline \multirow[t]{2}{*}{ Gerak gigi } & \multirow[t]{2}{*}{ Nilai uji korelasi } & \multicolumn{4}{|c|}{ Sel osteoklas } \\
\hline & & Kontrol & Aspirin & Diklonefak & Paracetamol \\
\hline \multirow{3}{*}{ Kontrol } & Korelasi pearson & 0.449 & & & \\
\hline & $\mathrm{p}$ & 0.372 & & & \\
\hline & $\mathrm{n}$ & 6 & & & \\
\hline \multirow{3}{*}{ Aspirin } & Korelasi pearson & & 0.521 & & \\
\hline & $p$ & & 0.289 & & \\
\hline & $\mathrm{n}$ & & 6 & & \\
\hline \multirow{3}{*}{ Diklonefak } & Korelasi pearson & & & 0.261 & \\
\hline & $p$ & & & 0.617 & \\
\hline & $\mathrm{n}$ & & & 6 & \\
\hline \multirow{3}{*}{ Paracetamol } & Korelasi pearson & & & & 0.666 \\
\hline & $p$ & & & & 0.149 \\
\hline & $\mathrm{n}$ & & & & 6 \\
\hline
\end{tabular}

Keterangan : Dinyatakan ada korelasi apabila $0,2 \leq r$ atau $r \leq-0,2$. Korelasi bermakna apabila $p \leq 0,05 . n=$ jumlah sampel

Uji Korelasi Pergerakan Gigi dengan Jumlah Sel Osteoblas dan Uji Korelasi Jumlah Sel Osteoklas dengan Osteoblas

Uji korelasi hubungan antara pergerakan gigi dengan jumlah sel osteoklas dan osteoblas (Tabel 9) menunjukkan bahwa pada perlakuan tanpa pemberian obat dan dengan pemberian diklofenak dan paracetamol, terdapat hubungan tetapi tidak bermakna. Hal ini berhubungan dengan hari perlakuan. Pada hari ke tiga dikatakan bahwa osteoklas sedang berada dalam puncak aktivitas dan berlanjut sanmpai pada hari ke 7, sedangkan osteoblas baru mulai teraktivasi dan dalam puncak aktivasi pada hari ke 14 [13]. Jumlah sel osteoklas dan osteoblas pada perlakuan dengan pemberian aspirin, diklofenak, dan paracetamol, terjadi penurunan dibandingkan dengan kontrol tanpa pemberian obat.

Tabel 9. Korelasi pearson antara pergerakan gigi dengan jumlah sel osteoblas

\begin{tabular}{|c|c|c|c|c|c|}
\hline \multirow{2}{*}{ Gerak gigi } & \multirow{2}{*}{ Nilai uji korelasi } & \multicolumn{4}{|c|}{ Sel osteoblas } \\
\hline & & Kontrol & Aspirin & Diklonefak & Paracetamol \\
\hline \multirow{3}{*}{ Kontrol } & Korelasi pearson & -0.216 & & & \\
\hline & $\mathrm{p}$ & 0.681 & & & \\
\hline & $n$ & 6 & & & \\
\hline \multirow{3}{*}{ Aspirin } & Korelasi pearson & & $0.879 *$ & & \\
\hline & $p$ & & 0.021 & & \\
\hline & $\mathrm{n}$ & & 6 & & \\
\hline \multirow{3}{*}{ Diklonefak } & Korelasi pearson & & & 0.494 & \\
\hline & $\mathrm{p}$ & & & 0.319 & \\
\hline & $\mathrm{n}$ & & & 6 & \\
\hline \multirow{3}{*}{ Paracetamol } & Korelasi pearson & & & & 0.294 \\
\hline & $\mathrm{p}$ & & & & 0.572 \\
\hline & $n$ & & & & 6 \\
\hline
\end{tabular}

Keterangan : Dinyatakan ada korelasi apabila $0,2 \leq r$ atau $r \leq-0,2$. Korelasi bermakna apabila $p \leq 0,05 . n=$ jumlah sampel

Tabel 10. Korelasi pearson antara jumlah sel osteoklas dengan osteoblas

\begin{tabular}{|c|c|c|c|c|c|}
\hline \multirow{2}{*}{ Sel osteoblas } & \multirow{2}{*}{ Nilai uji korelasi } & \multicolumn{4}{|c|}{ Sel osteoklas } \\
\hline & & Kontrol & Aspirin & Diklonefak & Paracetamol \\
\hline \multirow{3}{*}{ Kontrol } & Korelasi pearson & 0.152 & & & \\
\hline & $\mathrm{p}$ & 0.773 & & & \\
\hline & $\mathrm{n}$ & 6 & & & \\
\hline \multirow{3}{*}{ Aspirin } & Korelasi pearson & & 0.112 & & \\
\hline & $\mathrm{p}$ & & 0.833 & & \\
\hline & $\mathrm{n}$ & & 6 & & \\
\hline \multirow{3}{*}{ Diklonefak } & Korelasi pearson & & & $0.946 * *$ & \\
\hline & $p$ & & & 0.004 & \\
\hline & $\mathrm{n}$ & & & 6 & \\
\hline \multirow{3}{*}{ Paracetamol } & Korelasi pearson & & & & 0.006 \\
\hline & $\mathrm{p}$ & & & & 0.992 \\
\hline & $\mathrm{n}$ & & & & 6 \\
\hline
\end{tabular}

Keterangan : Dinyatakan ada korelasi apabila $0,2 \leq r$ atau $r \leq-0,2$. Korelasi bermakna apabila $p \leq 0,05 . n=$ jumlah sampel 
Tetapi pada uji korelasi hubungan antara jumlah sel osteoblas dengan jumlah sel osteoklas (Tabel 10) menunjukkan bahwa hanya pada perlakuan dengan pemberian aspirin terdapat hubungan yang sangat bermakna. Hal ini juga berhubungan dengan hari perlakuan karena perbedaan hari aktivasi dari sel osteoklas dan sel osteoblas.

\section{KESIMPULAN}

Pemberian aspirin, diklofenak, dan paracetamol pada pemakaian alat ortodontik menghambat produksi $\mathrm{PGE}_{2}$ tulang alveolus rahang melalui hambatan kerja enzim $\operatorname{cox} 1,2$, dan 3. Pemberian OAINS selektif $\operatorname{cox} 1$, selektif $\operatorname{cox} 2$, dan non OAINS pada pemakaian alat ortodontik selama 3 hari tidak mempengaruhi besar pergerakan gigi. Pemberian OAINS selektif $\operatorname{cox} 1$, selektif $\operatorname{cox} 2$, dan non OAINS pada pemakaian alat ortodontik selama 3 hari tidak menurunkan jumlah sel osteoklas dan osteoblas secara nyata. Selain itu kadar $\mathrm{PGE}_{2}$ yang menurun pada OAINS selektif cox 1 , selektif cox 2 , dan non OAINS tidak berpengaruh pada proses pergerakan gigi pada pemakaian alat ortodontik selama 3 hari. Kadar $\mathrm{PGE}_{2}$ yang menurun pada pemberian OAINS selektif cox 1 , selektif cox 2, dan non OAINS tidak cukup mempengaruhi penurunan jumlah sel osteoklas dan osteoblas tulang alveolus rahang akibat pemakaian alat ortodontik selama 3 hari. Pergerakan gigi pada pemberian OAINS selektif $\operatorname{cox} 1$, selektif $\operatorname{cox} 2$, dan non OAINS tidak berpe-ngaruh pada jumlah sel osteoklas dan osteoblas tulang alveolus rahang akibat pemakaian alat ortodontik selama 3 hari.

\section{DAFTAR PUSTAKA}

[1] Buletin Mingguan Melsa. 2002. Tampil Cantik dengan Kawat Gigi. Melsa-i-net Weekly Bulletin 1-3.

[2] Situs Gigi Indonesia. 2001. Solusi bagi yang ingin giginya rapi. Konsultasi gigi.com. h. 13.http://www/konsultasiGIGI_com-situs gigi Indonesia-Topik Juni 2001.htm

[3] Soeatmadji, J. W. 2002. Kendali Hormonal Metabolisme Calsium dan Skeletal. Dalam: Soeatmadji, D. W., A. Rudijanto, P. M. Arsana (Eds). Kursus Dasar Metabolisme Kalsium dan Penyakit Tulang. Laboratorium Biomedik, Fakultas Kedokteran, Universitas Brawijaya, Malang. PB. Perkeni. IV (3).

[4] Nulend, J. K., E. H. Burger. 1999. Prostaglandins and Bone. Department of
Oral Cell Biology. The European Calcified Tissue Society, 1-8. http://www.etcsoc. org/review/006_klei.htm.

[5] Bandolier. 2002. Do NSAIDs Inhibit bone healing?. Evidence Based Health Care. http://www/DoNSAIDsInhibitBoneHealing.h tm.

[6] Feldman, M., T. A. McMahon. 2000. Do siclooxigenase-2 inhibitor provide benefits similar to those of tradisional nonsteroidal anti-inflammatory drugs, with less gastrointestinal toxicity?. Ann. Intern. Med. 132 (2). 134-43.

[7] Forsea, J. N. 1997. Physiologic changes in orthodontists in response to spesific orthodontic procedures. Orthodontics Research NYU College of Dentistry, 1-19.

[8] Yamasaki, K., F. Miura, T. Suda. 1980. Prostaglandin as a mediator of bone resorption induced by experimental tooth movement in rats. J. Dent. Rest. 59(10). 1635-1642.

[9] Chandrasekharan, N. V., H. Dai, K. L. Roos, N. K. Evanson, J. Tomsik, T. S. Elton, D. L. Simmons. 2002. Cox 3, a cyclooxygenase 1 variant inhibited by acetaminophen and other analgesic/ antipyretic drugs: cloning, structure, and expresion. Department of Chemistry and Biochemistry. 99 (21). 1337113373.

[10] Giunta, D., J. Keller, F. F. Nielson, B. Melson. 1995. Influence of Indometracin on bone turnover related to orthodontic tooth moverment in miniature pigs. Am. Assoc. Orthod. 108 (4). 361-365.

[11] King, G. J., L. Latta, J. Rutenberg, A. Ossi, S. D. Kelling. 1997. Alveolar bone turnover and tooth movement in male rats after removal of orthodontic appliances. Am. J. Orthod. Dentofac Orthop. 111(3). 266-275.

[12] Setyohadi, B. 2007. Osteoporosis. Buku ajar penyakit dalam. Fakultas Kedokteran, Universitas Indonesia. Jakarta. 1259-1274.

[13] Domon, S., H. Shimokawa, S. Yamaguchi, K. Soma. 2000. Temporal and spatial mRNA expression of bone sialoprotein and type I collagen during rodent tooth movement. Eur. J. Orthod. 23(4). 339-48.

[14] Yun Cho. 1996. A histologic study of The alveolar bone remodelling on The Periosteal side incident to experimental tooth movement. Dentistry in Japan. 33. 79-82.

[15] Dradjat, R. S. 2002. Struktur dan fungsi skeleton. Dalam: Soeatmadji, D. W., A. Rudijanto, P. M. Arsana (Eds). Kursus Dasar 
Metabolisme Kalsium dan Penyakit Tulang.

Laboratorium Biomedik, Fakultas

Kedokteran, Universitas Brawijaya, Malang. PB. Perkeni. III. 1-9.

[16] Brian, D., Golden, and S.B. Ambramson. 1999. Selective COX-2 Inhibitors for Arthritis: from Bench to Beside. Cutting Edge Report. Department of Rheumatology, Hospital for Joint Diseases. New York University School of Medicine. 1-4. http://www.rheuma21st.com.

[17] Suryana, B. P. P., H. Kalim. 2002. Osteoporosis primer. Dalam: Soeatmadji, D. W., A. Rudijanto, P. M. Arsana (Eds). Kursus Dasar Metabolisme Kalsium dan Penyakit Tulang. Laboratorium Biomedik, Fakultas Kedokteran, Universitas Brawijaya, Malang. PB. Perkeni. VII.

[18] Melsen, B. 2001. Tissue reaction to orthodontic tooth movement-a new paradigm. Eur. J. Orthod. 23 (6). 671-81.

[19] Calabrese, E. J. 2001. Prostaglandins: biphasic dose responses. Critical Rev. Toxicol. 31(4-5). 475-487.

[20] Kreutz, S. 2002. Prostaglandins-hormonelike substances with great potential, 1-4. http://www/Jamulndonesia_com-prosta glandins-hormons-like substances.htm 